\title{
KOORDYNACJA BEZPIECZEŃSTWA IMPREZ MASOWYCH W PRAKTYCE I ROZWIAZZANIACH PRAWNYCH RP
}

Celem niniejszej publikacji jest przedstawienie zagadnień związanych z organizacją bezpieczeństwa imprez masowych, podejściem do tych zagadnień od strony prawnej i praktycznej oraz analiza filozofii działania w tym obszarze na przestrzeni ostatnich 20 lat.

Zaangażowanie sił policyjnych ma decydujące znaczenie dla bezpieczeństwa imprez masowych, zwłaszcza tych o charakterze sportowym. Policja szczególną uwagę przywiązuje do zabezpieczenia meczy piłki nożnej. Niestety, to właśnie kibice piłkarscy generują najwięcej negatywnych zachowań w postaci pobić, bójek, rozbojów oraz czynnych napaści na funkcjonariuszy publicznych, spośród wszystkich innych kibiców skupionych wokół różnorodnych dyscyplin sportowych. Nie ma takiej drugiej dyscypliny sportu, która by wywoływała wśród kibiców tak olbrzymie emocje, nie tylko na stadionie $\mathrm{w}$ trakcie trwania widowiska, ale i poza nim jeszcze na długo przed jego rozpoczęciem czy po zakończeniu. Tak jak piłkarze, również kibice chcą za wszelką cenę udowodnić swój prymat, przy czym wynik sportowych zmagań ich idoli często nie ma żadnego znaczenia. W odniesieniu do szczególnej grupy jaką stanowią chuligani stadionowi nierzadko dochodzi do zbiorowych zakłóceń bezpieczeństwa i porządku publicznego. Znane są też przypadki zagrożenia do jakich dochodziło podczas meczów hokeja na lodzie lub ligi żużlowej, jednak niezwykle rzadko przenosiły się one poza stadion. Zjawiska zakłócenia bezpieczeństwa podczas spektakli o charakterze sportowym mają swoją długoletnią historię, sięgają one czasów Imperium Rzymskiego. W 532 r. w Bizancjum doszło do zamieszek wśród widzów, którzy domagali się zastosowania prawa łaski dla skazanych, co w konsekwencji doprowadziło do zdobycia budynku prefektury oraz uwolnienia przetrzymywanych tam więźniów (Krawczuk, 1992: 136). Jednak historia zmagań sportowych narodziła się dużo wcześniej w Grecji. Jak głosi jedna z legend, Zeus po stoczeniu w Olimpii walki ze swoim ojcem Kronosem o panowanie nad światem, ustanowił tam igrzyska dla uczczenia swojego zwycięstwa. Czy w istocie przykład ten nie przedstawia też dążeń z jakimi mamy do czynienia współcześnie? Czym są Mistrzostwa Świata w Piłce Nożnej czy Mistrzostwa Europy? Zapewne próbą panowania, czy to na świecie czy w Europie, w obrębie dyscypliny sportu jaką jest piłka nożna. Tak jak Zeus chciał zapanować nad światem, tak i współcześni gladiatorzy piłkarscy, którym niejednokrotnie przypisywane są określenia „boski”, co cztery lata walczą, a potem przywdziewają korony mistrzów, nosząc je z dumą do czasu kolejnych zmagań, na które czekają miliony ich zwolenników. Współczesne zmagania opierają się na sportowej walce, w której 
zasady czystej gry (fair play) mają ogromne znaczenie. Niestety nie zawsze zasady ducha sportu, jakie prezentują idole, są akceptowane przez tych, którzy ich podziwiają. Bywa, że w takich sytuacjach chodzi nie o sportowe panowanie zdobyte w uczciwej walce, a o fizyczne udowodnienie, niekiedy w trakcie brutalnych walk na pięści, swojej wyższości jednych nad drugimi.

Zjawisko to dotyczy przede wszystkim piłkarskich rozgrywek klubowych o charakterze krajowym, jednak historyczne uwarunkowania, tradycyjne waśnie czy aktualne stosunki społeczno-polityczne pomiędzy poszczególnymi krajami mogą prowadzić do zachowań agresywnych między kibicami, a raczej pseudokibicami piłkarskich reprezentacji krajowych. Niestety, zjawisko chuligaństwa stadionowego pojawiło się też w Polsce. Moje pierwsze doświadczenia zawodowe związane z zabezpieczeniem imprez sportowych miały miejsce w końcu lat 70 . i na początku lat 80 . w Poznaniu. Już wtedy podczas meczy piłkarskich między Kolejowym Klubem Sportowym Lech Poznań (zwanym w gwarze poznańskiej Kolejorzem) a Wojskowym Klubem Sportowym Ślask Wrocław dochodziło do napięć i uzewnętrzniania agresji w stosunku do kibiców, jak i Milicji. Spostrzeżenia te potwierdzają Konrad Kołek i Mieczysław Mikołajczyk, którzy zauważają że narodzin zjawiska chuligaństwa stadionowego w Polsce, występującego na terenie obiektów piłkarskich, doszukiwać się można u progu lat 70., natomiast znaczny wzrost liczebności grup tzw. szalikowców został odnotowany na początku lat 80. (Kołek, Mikołajczyk, 2010: 36). W tych latach Milicja, a następnie Policja z różnym skutkiem radziły sobie ze zjawiskiem chuligaństwa stadionowego, które $\mathrm{w}$ wielu przypadkach przejawiało się w formie bijatyk pomiędzy kibicami zwaśnionych drużyn lub zdecydowanych ataków na siły porządkowe. Kibice piłkarscy znani są też z histerycznych reakcji, niejednokrotnie media donosiły o wyrzucanych na ulicę telewizorach po przegranej drużyny. Barbara Karolczak-Biernacka uważa nawet, że zachowania kibiców mogą prowadzić do samoagresji i w konsekwencji powodować targnięcie się na własne życie z powodu rezultatów sportowych niezgodnych z oczekiwaniami (Karolczak-Biernacka, 2001: 8).

W wielu opracowaniach dotyczących zjawisk chuligaństwa stadionowego używa się określeń kibice i pseudokibice. W pierwszym przypadku mamy do czynienia z tymi, którzy w sposób pozbawiony agresji w stosunku do innych potrafią skoncentrować się na widowisku sportowym, nie szukając innych pozasportowych wrażeń. Pogląd taki przedstawia również Jerzy Dudała twierdząc, że prawdziwy kibic w sposób kulturalny i na poziomie wyraża swoje poglądy podczas meczów, propagując zachowania etyczne w sporcie i zdrową rywalizację (Dudała, 2004: 22-23). Przyjmując, iż pseudokibice prezentują odwrotne postawy, łatwo można scharakteryzować ich filozofię, która będzie polegała na braku kultury i etyki w zachowaniu, zarówno na stadionie, jak i poza nim. Pamiętać jednak należy, że choć taki podział dość często występuje w literaturze przedmiotu, to jednak i ten kulturalny kibic w określonych sytuacjach może zostać „porwany” przez thum i przejawiać zgoła inne zachowania. Pisze o tym między innymi Agata Tyburska uważając, że oddziaływanie agresywnego thumu potęguje zachowania społeczne (Tyburska, 2010: 79). Tłum zatem potrafi wyzwolić negatywne emocje również i u tych, którzy dotychczas mogli być uważani za prawdziwych kibiców. Z pozoru spokojni kibice, kiedy znajdą się w polu oddziaływania thumu, często przejawiają zachowania agresywne. Zjawisko to jest znane w psychologii i określane 
mianem zachowania modelującego, które oznacza poddanie się temu, co w danym momencie realizuje większość, np. inni uczestnicy imprezy masowej. Spotykane są jednak również działania kierunkowe, celowe, gdzie w skrajnych przypadkach dochodziło, a co gorsza nadal dochodzi, do powoływania bojówek spośród najbardziej agresywnych pseudokibiców, które w sposób niezwykle brutalny rozprawiają się ze zidentyfikowanym przeciwnikiem, czyli kibicami drużyn przeciwnych, jak też w sposób bezpardonowy atakują Policję.

Dominującym rozwiązaniem jakie w latach 80. i 90. przyjmowały Milicja i Policja było przeciwstawienie się agresji poprzez delegowanie do służby uzbrojonych funkcjonariuszy Oddziałów Prewencji, a jeszcze wcześniej Zmotoryzowanych Odwodów Milicji Obywatelskiej, które potrafily w adekwatny sposób przeciwstawić się takim zachowaniom, zazwyczaj przy zastosowaniu siły i innych środków przymusu bezpośredniego. Jedno w owym czasie było pewne - za bezpieczeństwo imprez masowych odpowiadały Milicja, a później Policja. Można nawet zaryzykować stwierdzenie, że bezpieczeństwo spotkań piłkarskich było jedynie troską Policji. W takich warunkach zaistniała konieczność poszukiwania nowych rozwiązań, zwłaszcza że tych zagrożeń pojawiało się coraz więcej. W trakcie dyskusji praktyków i teoretyków postulowano konieczność stworzenia ram prawnych definiujących imprezy masowe i określających obowiązki podmiotów operujących w tym obszarze. Tak rodziła się idea pierwszej w historii Polski ustawy o bezpieczeństwie imprez masowych. Grzegorz Gozdór zwraca uwagę na fakt, iż uchwalenie ustawy w 1997 r. poprzedziło wiele zdarzeń, które miały miejsce w szczególności na stadionach piłkarskich, jak również podczas koncertów rockowych. Zdarzeniem stanowiącym impuls do podjęcia zdecydowanych działań legislacyjnych dotyczących materii bezpieczeństwa i porządku podczas imprez masowych był z pewnością pożar w czasie koncertu w hali Stoczni Gdańskiej 24 listopada 1994 r., na skutek którego śmierć poniosło 7 osób, ponad 300 zaś odniosło obrażenia, a także kilkaset chuligańskich ekscesów, które zaszły podczas meczów piłki nożnej w latach 1995-1997 (Gozdór, 2008: 33). Brak uregulowań prawnych w tej kwestii powodował beztroskę organizatorów w odniesieniu do tego elementu organizacyjnego imprezy.

Rok 1997 był przełomowy w tym względzie, bowiem 22 sierpnia ustawodawca uchwalił ustawę o bezpieczeństwie imprez masowych (Ustawa, 1997). Art. 5 tego aktu prawnego nakładał w sposób jednoznaczny obowiązek zapewnienia bezpieczeństwa uczestnikom imprezy masowej przez organizatora: „organizator imprezy jest obowiązany do zapewnienia bezpieczeństwa osobom obecnym na imprezie oraz porządku podczas trwania imprezy". Niestety przepis ten, w początkowej fazie jego obowiązywania, był realizowany jedynie w sposób formalny. Stereotyp myślenia powodował, że organizatorzy nadal uważali, iż ta odpowiedzialność spoczywa na Policji. Niemniej, co warto zauważyć, były to pierwsze rozwiązania zmierzające do tak zwanej prywatyzacji bezpieczeństwa, co w ogólnym znaczeniu można określić jako cedowanie odpowiedzialności za ten obszar na inne podmioty niż Policja1. Traktowanie przez organizatora obowiązku zapewnienia bezpieczeństwa jako zła koniecznego wynikało z jednej strony ze sporych kosztów wynajęcia profesjonalnej służby ochrony, co

${ }^{1}$ Szerzej na ten temat zob.: G. Gozdór (2012), Prywatyzacja bezpieczeństwa. Rola i miejsce prywatnego sektora ochrony w systemie bezpieczeństwa i porzqdku publicznego, Lublin. 
w sposób zasadniczy zmniejszało zyski z planowanego przedsięwzięcia, z drugiej strony szczupłość budżetu wielu klubów, szczególnie niższych klas piłkarskich rozgrywek, nie pozwalała na wywiązanie się z wymogu ustawowego. Formalizm, o którym wspomniano wyżej, ograniczał się najczęściej do realizacji wymogów dokumentacyjnych, między innymi takich, jak: wypełnienie niezbędnych wniosków, uzyskanie pozwolenia oraz zapewnienie w odpowiedniej liczbie służb porządkowych, które najczęściej były rekrutowane doraźnie, spośród sympatyków danej dyscypliny sportu lub szerokiego kręgu działaczy skupionych wokół danego klubu. Nie miało to szczególnego wpływu na poprawę elementów bezpieczeństwa podczas realizacji zabezpieczenia imprez, szczególnie meczów piłki nożnej, tym samym nie przynosiło oczekiwanych zmian jakościowych. Nie oznacza to jednak, że można negować, co do zasady, przyjęte rozwiązania. Pogląd ten podzielają Wojciech Kotowski i Bolesław Kurzępa oceniając, iż zasada przyjęta w art. 5 ust. 1 ustawy o odpowiedzialności organizatora jest par excellence słuszna. Chodzi w niej wszakże o wykazanie się największą starannością $\mathrm{w}$ przygotowaniu imprezy, a w jej ramach spełnienie stawianych wymagań ustawowych (Kotowski, Kurzępa, 2010: 48). Policja, działając w myśl nowych przepisów, starała się po $1997 \mathrm{r}$. konsekwentnie wymuszać na organizatorach dostosowanie się do wprowadzonych zmian, co oznaczało zaangażowanie się ich w proces budowy bezpieczeństwa imprez. W niektórych jednostkach podejmowano decyzję o powolnym wycofywaniu swoich sił z obiektów sportowych. Nie zawsze było to jednak możliwe z uwagi na ciagle słabe wyszkolenie służb porządkowych, gdyż specjalistyczne formacje ochrony zajmujące się bezpieczeństwem imprez masowych dopiero powstawały i nabierały niezbędnego doświadczenia. $\mathrm{W}$ tych warunkach trudno się dziwić, że organizatorzy idąc po linii najmniejszego oporu, nie będąc też dodatkowo zmuszeni przez ustawodawcę, wybierali najtańsze warianty zabezpieczenia, nie zwracając najczęściej uwagi na jakość podległych służb porządkowych, wciąż mając nadzieję na profesjonalne i fizyczne wsparcie elementu bezpieczeństwa ze strony Policji. Takie oczekiwania nie były bezpodstawne, albowiem w warunkach obowiazzywania pierwszej ustawy o bezpieczeństwie imprez masowych uprawnieniem organizatora było ujęcie przez służby porządkowe osób stwarzających zagrożenie w celu niezwłocznego przekazania ich Policji. Termin niezwłoczny ${ }^{2}$ nie jest jednak łatwy do określenia, choć po analizie literatury należy dojść do wniosku, że oznacza on działanie bez zbędnej zwłoki. Tym samym wydaje się uzasadnione twierdzenie, że do wypełnienia tego wymogu konieczna była bliskość przebywania sił policyjnych. Ponadto art. 17 ust. 2 przewidywał możliwość wystapienia organizatora o pomoc ze strony Policji, gdyby działania służb porządkowych okazały się nieskuteczne. To również uzasadniało konieczność dyslokowania funkcjonariuszy Policji w obszarze bezpośrednim dla imprezy masowej. Trudno bowiem sobie wyobrazić, że dopiero w sytuacji poważnego zakłócenia porządku na stadionie organizator będzie zwracał się z prośbą o interwencję do jednostki Policji, która nie była w pełni przygotowana do działań, gdyż nie przewidziała odpowiedniej liczby policjantów mogących przywrócić naruszony ład i porządek. Takie zachowanie należałoby uznać za spóźnione i mogące prowadzić do znaczącej eskalacji zachowań

${ }^{2}$ Na gruncie prawa cywilnego, zwłaszcza przy okazji wykładni art. 455 k.c., dominował pogląd, że termin „niezwłocznie” oznacza termin realny, mający na względzie okoliczności danego miejsca i czasu, http://legalista.home.pl/blog/wordpress/?p=101 (8.08.2016). 
uczestników imprezy masowej, co w konsekwencji i tak musiałoby przełożyć się na konieczne poszukiwanie winnych zaniedbań. Jak łatwo przewidzieć, oskarżenia w takim przypadku dotyczyłyby zarówno organizatora, jak i Policji.

Kolejnym obowiązkiem organizatora, uzasadniającym konieczność udziału Policji w systemie zabezpieczenia imprez, a wynikającym z art. 5 ust. 1 pkt 7, było ,zapewnienie w razie potrzeby pomieszczenia dla służb kierujących zabezpieczeniem". Czyżby zatem ustawodawca celowo nie powielił tu określenia ,służby porządkowe”, wprowadzając $w$ to miejsce dodatkowy podmiot lub podmioty? A może uznano, że kierowanie bezpieczeństwem należy powierzyć komuś innemu (w domyśle Policji)? Wszystkie te wątpliwości czy pewne niedookreślenia nie zmieniają ogólnej oceny celowości uchwalenia ustawy i pierwszej próby uporządkowania tej problematyki. To, że dotychczasową praktykę, stosowaną przed wejściem w życie nowych przepisów w marcu $1998 \mathrm{r}$. (przepisy przewidywały 6-miesięczne vacatio legis), a polegającą na szerokim udziale sił policyjnych w zabezpieczeniu imprez masowych, trudno było zmienić, stanowiło też konsekwencję dużego zaufania organizatorów imprez do zabezpieczających je dotychczas, dobrze przygotowanych, mających wieloletnie doświadczenie funkcjonariuszy reprezentujących Oddziały Prewencji ${ }^{3}$. Mimo nowych obowiązków nałożonych na organizatora przez ustawodawcę Komendanci Wojewódzcy i Rejonowi Policji nie mogli czuć się zwolnieni z obowiązku uczestnictwa w zabezpieczeniu tych imprez. Musieli przecież brać pod uwagę regulacje wynikające z art. 1 ust. 2 pkt 2 ustawy o Policji (Ustawa, 1990), która nakładała na nich obowiązek ochrony bezpieczeństwa i porządku publicznego, w tym zapewnienia spokoju w miejscach publicznych oraz w środkach komunikacji publicznej i w ruchu drogowym. Kierując się tym przepisem i zrozumiałą troską o szeroko rozumiane bezpieczeństwo, część kierowników jednostek nadal utrzymywała swoje siły na stadionach, w wydzielonych do tego sektorach, inni zaś utrzymywali siły policyjne w obrębie imprezy masowej, nie na stadionie, lecz w bezpośredniej jego bliskości, tak by mieć gwarancję natychmiastowego ich użycia w przypadku zakłócenia bezpieczeństwa i porządku publicznego, w sytuacji, gdyby siły porządkowe nie mogły sprostać temu wyzwaniu. Było to najczęściej stosowane rozwiązanie przy jednoczesnym zapewnieniu dowódcy sił policyjnych możliwości obserwacji przebiegu imprezy i elastycznego reagowania na pojawiające się zagrożenia w wydzielonym specjalnie do tego celu pomieszczeniu przeznaczonym dla służb kierujących zabezpieczeniem. Należy przyjąć, że choć odpowiedzialność za zapewnienie bezpieczeństwa spoczywała na organizatorze, to szczególnie w przypadku poważniejszych wyzwań, np. rozgrywek piłkarskich, za koordynowanie zagadnień związanych z bezpieczeństwem odpowiadali policjanci. Warto w tym momencie zwrócić szczególną uwagę na kwestie związane z koordynacją działań, dokonując analizy, niedocenianego w pełni wówczas zapisu ustawowego, który określał co ustawodawca rozumie przez pojęcie zabezpieczenia imprezy masowej. Na podstawie art. 3 ust. 2 zdefiniowano to pojęcie jako „ogół skoordynowanych przedsięwzięć podejmowanych przez organizatora imprezy, wójta, burmistrza, prezydenta miasta, wojewodę, Policję,

3 To jednostki organizacyjne Policji, przeznaczone głównie do działań w ramach pododdziałów zwartych, których głównym zadaniem jest ochrona bezpieczeństwa i porządku publicznego w trakcie trwania zgromadzeń i imprez masowych oraz przywracanie porządku publicznego w przypadku zbiorowego naruszenia jego prawa. 
Państwową Straż Pożarną i inne jednostki organizacyjne ochrony przeciwpożarowej, służbę zdrowia, a w razie potrzeby przez inne właściwe służby i organy". Ogół skoordynowanych przedsięwzięć to zarazem wspólne działanie i wspólna odpowiedzialność wskazanych podmiotów. Tym samym pogląd na temat konieczności udziału sił policyjnych w zabezpieczeniu imprez masowych należy przyjąć za uzasadniony. Podobne stanowisko przedstawia, cytowany już wcześniej, Grzegorz Gozdór, który opisując zakres zadań służb ochrony stwierdza, że nie można bezwzględnie wykluczyć pomocy czy interwencji Policji zarówno w przypadku zagrożeń bezpieczeństwa wymienionych w ustawie o ochronie osób i mienia jednostek objętych ochroną, jak i w przypadku poważnego naruszenia bezpieczeństwa odpłatnej imprezy masowej (Gozdór, 2008: 36). Pogląd słuszny, lecz w obliczu wcześniej przedstawionych i przeanalizowanych uregulowań prawnych należy przyjać, że nie tylko nie można było wykluczyć pomocy czy interwencji Policji, ale wprost jej oczekiwać.

Podsumowując, już w pierwszej wersji ustawy o bezpieczeństwie imprez masowych wskazano, co bardzo ważne, na konieczny udział w procesie budowy bezpieczeństwa wielu istotnych podmiotów. Pozostawało jednak otwartym pytanie, kto powinien realizować funkcję głównego koordynatora? Jeżeli miałby to być organizator, to nie miał on przecież wystarczających możliwości ani kompetencji do koordynacji działań wymienionych podmiotów, zwłaszcza Policji czy Państwowej Straży Pożarnej. Jeżeli mieliby to być wójtowie, prezydenci czy wojewodowie, to można się doszukać przysługujących im pewnych kompetencji prawnych, pozostaje jednak duża wątpliwość co do tego, czy dysponowali oni niezbędnymi specjalistami w tej dziedzinie? To zatem, że policjanci w sposób oczywisty, wynikający z długoletniego doświadczenia, odgrywali zasadniczą rolę $\mathrm{w}$ systemie bezpieczeństwa wewnętrznego, czuli się odpowiedzialni i za ten odcinek działań, nie może dziwić. Jednak sprawa konieczności uregulowania kwestii koordynatora pozostawała nadal otwarta. Podobny pogląd prezentuje Leszek Dyduch uznając, że naturalnym kandydatem do pełnienia funkcji koordynatora działań na rzecz zapewnienia bezpieczeństwa imprez masowych jest Policja (Dyduch, 2010: 270). Niestety w takich warunkach prawnych, przy braku wskazania głównego lidera, trudno było mówić o właściwej koordynacji, była to raczej realizacja zadań w ramach kompetencji oddzielnie wskazanych podmiotów aniżeli skoordynowane działanie ich wszystkich $w$ jednym obszarze i nad jednym zagadnieniem. Tym obszarem było oczywiście bezpieczeństwo imprezy masowej, stanowiące element zagrożeń o charakterze publicznym. Nie powinien jednak nikogo dziwić fakt, że Policja niechętnie przyjmowała i przyjmuje na siebie ciężar realizacji nowych obowiązków, albowiem tych przybywa z każdym rokiem, a stan liczebny sił policyjnych nie zmienia się od kilkunastu lat. Ponadto podjęcie się roli koordynatora systemu bezpieczeństwa imprez masowych mogłoby być odczytane, przez podmioty uczestniczące w zabezpieczeniu, jako przejęcie głównego ciężaru odpowiedzialności, a ten etap historycznie został zamknięty w $1997 \mathrm{r}$.

Zauważalny niekiedy, lekceważący stosunek organizatora do zobowiązań ustawowych, zwłaszcza pod rządami pierwszych rozwiązań prawnych związanych z bezpieczeństwem imprez masowych, mógł się również wiązać (obok braku elementarnej wiedzy i specjalistów) z brakiem sankcji karnych za niewywiązywanie się z obowiązku zapewnienia bezpieczeństwa, nie licząc odpowiedzialności organizatora za orga- 
nizację imprezy bez wymaganego zezwolenia lub wbrew wydanemu zakazowi oraz odpowiedzialności za szkody, jakie mogły powstać w mieniu Policji ${ }^{4}$. Dodatkowo sprzyjał też temu brak jakiejkolwiek sankcji karnej za niewykonanie lub zaniechanie wykonania obowiązków ustawowych nałożonych na służby porządkowe organizatora imprezy. Zdarzały się nawet przypadki nieformalnej współpracy pseudokibiców i służb ochrony polegające głównie na świadomym braku reakcji tych ostatnich w przypadku popełniania przestępstw czy wykroczeń w trakcie imprezy. Przykładem tak oburzającego i nieprofesjonalnego zachowania służb porządkowych była sytuacja na stadionie Lecha Poznań podczas meczu z Wista Kraków 30 października 2010 r. Znajdujący się w sektorze gości kibice Wisty Kraków, niezadowoleni z wyniku meczu, sprowokowali kibiców Lecha Poznań, którzy w sile kilkudziesięciu osób podbiegli do sektora zajmowanego przez gości, chcąc sforsować pleksiglasowe ogrodzenie i wtargnąć do tego sektora. Zdarzenie to zostało zauważone i opisane przez media w następujący sposób: „[...] w ostatnich minutach meczu Lecha z Wista z zajmowanego przez dwa tysiące kibiców Wisty sektora na boisko poleciały plastikowe butelki. Chwilę później chuligani zaczęli walić rękami w pleksiglasowe ogrodzenie i próbowali niszczyć siedzenia. Tuż obok zjawili się agresywni kibole Lecha. Nie ci, którzy mają bilety na sąsiadującą z sektorem gości I trybunę - dużo droższą i niezajmowaną przez najbardziej fanatycznych kibiców (często w literaturze określanych zamiennie jako kibole), w pobliże sektora zajmowanego przez Wisłę w ciagu kilkudziesięciu sekund bez problemów przybiegło kilkudziesięciu fanów Lecha z II trybuny, niektórzy w drodze zakładali zabronione na stadionach kominiarki. Nie niepokoili ich ochroniarze, którzy się rozpierzchli" (Ekstraklasa, 2010).

Kolejne ewolucje zmian prawnych, wykorzystujące zebrane doświadczenia, służyły doskonaleniu przepisów, lecz równocześnie sankcjonowaniu negatywnych zachowań po stronie obowiązków organizatora, w tym również zachowań służb ochrony. Bez wątpienia prace nad nowymi przepisami znacząco przyspieszyła konieczność zagwarantowania, na możliwie najwyższym poziomie, bezpieczeństwa Mistrzostw Europy w Piłce Nożnej EURO 2012. Wielokrotne nowelizacje ustawy z 1997 r. oraz wiele nowych postulatów dotyczących konieczności dalszych zmian, nie tylko tych o charakterze karnym, doprowadziły w rezultacie do uchwalenia nowej regulacji. Ostatecznie w ustawie o bezpieczeństwie imprez masowych z 20 marca 2009 r. (Ustawa, 2009) skodyfikowano szereg zachowań, które w sposób dość jednoznaczny wskazują na odpowiedzialność pod groźbą kary zarówno organizatora, jak i służb porządkowych, wyeliminowując tym samym dużą słabość pierwszych rozwiązań prawnych. W dalszym ciągu, co jest konsekwentną kontynuacją zapisu z 1997 r., za bezpieczeństwo imprezy masowej odpowiadał jej organizator. Art. 5 ust. 2 określił wymogi, jakie musi spełnić organizator takiej imprezy, do których zaliczono:

- zapewnienie bezpieczeństwa osobom uczestniczącym w imprezie;

${ }^{4}$ Zgodnie z art. 21 ust. 1 wspomnianej ustawy, odpowiedzialności karnej podlegał ten, kto organizował imprezę masową bez wymaganego zezwolenia lub przeprowadzał ją wbrew wydanemu zakazowi, ponadto na podstawie przepisów art. 19 ust. 1 organizator odpowiadał też za szkody, które poniosła Policja, Żandarmeria Wojskowa, straż gminna (miejska), Państwowa Straż Pożarna oraz służba zdrowia, w związku z ich działaniami w miejscu i czasie trwania imprezy masowej. 
- ochronę porządku publicznego;

- zabezpieczenie pod względem medycznym;

- zapewnienie odpowiedniego stanu technicznego obiektów budowlanych wraz ze służącymi tym obiektom instalacjami i urządzeniami technicznymi, w szczególności przeciwpożarowymi i sanitarnymi.

Ponadto art. 6 ust. 1 określał elementy, jakie organizator musi zapewnić:

- spełnienie wymogów określonych, w szczególności, w przepisach prawa budowlanego, w przepisach sanitarnych i przepisach dotyczących ochrony przeciwpożarowej;

- udział służb porządkowych, służb informacyjnych oraz kierującego tymi służbami kierownika do spraw bezpieczeństwa;

- pomoc medyczną;

- zaplecze higieniczno-sanitarne;

- wyznaczenie dróg ewakuacyjnych oraz dróg umożliwiających dojazd pojazdom służb ratowniczych i Policji;

- warunki do zorganizowania łączności pomiędzy podmiotami biorącymi udział w zabezpieczeniu imprezy masowej;

- sprzęt ratowniczy i gaśniczy oraz środki gaśnicze niezbędne do zabezpieczenia imprezy masowej w zakresie działań ratowniczo-gaśniczych;

- wydzielone pomieszczenia dla służb kierujących zabezpieczeniem imprezy masowej.

Odmiennie niż w 1997 r., tym razem niewywiązanie się z powyższych wymogów zostało usankcjonowane przez art. 59, który w całości przedstawiał się następująco:

„1. Kto organizuje imprezę masową bez wymaganego zezwolenia lub niezgodnie $\mathrm{z}$ warunkami określonymi w zezwoleniu albo przeprowadza ją wbrew wydanemu zakazowi podlega grzywnie nie mniejszej niż 240 stawek dziennych, karze ograniczenia wolności albo pozbawienia wolności od 6 miesięcy do lat 8 .

2. Kto, organizując imprezę masową, nie zachowuje wymogów i warunków bezpieczeństwa określonych $\mathrm{w}$ art. 5 ust. 2 lub w art. 6 ust. 1 podlega grzywnie nie mniejszej niż 180 stawek dziennych.

3. Tej samej karze podlega, kto będąc członkiem służby porządkowej lub służby informacyjnej, przekraczając swoje uprawnienia lub niedopełniając obowiązków, powoduje zagrożenie bezpieczeństwa imprezy masowej”.

Całkowicie zatem zmieniły się oczekiwania wobec organizatora. Obok sankcjonowania, przewidzianego w obu rozwiązaniach prawnych tak z 1997 r., jak i 2009 r., odpowiedzialności za organizację imprezy bez zezwolenia lub niezgodnie z jej warunkami albo wbrew zakazowi, w nowej regulacji wprowadzono wiele warunków i wymogów, których niespełnienie przez organizatora powoduje odpowiedzialność karną. Aby nie dochodziło do przypadków braku reakcji na niezgodne z prawem zachowania kibiców, które przedstawione zostały wcześniej na podstawie wydarzeń w Poznaniu, lub nadużywania swoich uprawnień, wprowadzono odpowiedzialność służb porządkowych i informacyjnych za przekroczenie oraz niedopełnienie wskazanych w ustawie obowiązków. Bezsprzecznie wzrosła tym samym rola służb porządkowych, a tym samym pojawiła się duża troska o jakość pracy tych służb.

Niezmienne pozostało stanowisko ustawodawcy co do określenia pojęcia zabezpieczenia imprezy masowej. Zgodnie z art. 3 ust. 16 należy przez to rozumieć „ogół 
skoordynowanych przedsięwzięć podejmowanych w celu zapewnienia bezpieczeństwa i porządku publicznego w związku z imprezą masową". Porównując to z zapisem prezentowanej już wcześniej ustawy z 1997 r., w której na postawie art. 3 ust. 2 definiowano to pojęcie jako „ogół skoordynowanych przedsięwzięć podejmowanych przez organizatora imprezy, wójta, burmistrza, prezydenta miasta, wojewodę, Policję, Państwową Straż Pożarną i inne jednostki organizacyjne ochrony przeciwpożarowej, służbę zdrowia, a w razie potrzeby przez inne właściwe służby i organy", w nowej ustawie zrezygnowano ze wskazania podmiotów biorących udział w tym procesie, jednak nadal uznano, że zabezpieczenie imprezy to szereg skoordynowanych działań. Natomiast tych, na których spoczywa obowiązek zabezpieczenia imprezy, wskazano w art. 5 ust. 3, którego przepis brzmi następująco: „Obowiązek zabezpieczenia imprezy masowej spoczywa na organizatorze, a w zakresie określonym w tej ustawie i innych przepisach także na wójcie, burmistrzu, prezydencie miasta, wojewodzie, Policji, Państwowej Straży Pożarnej i innych jednostkach organizacyjnych ochrony przeciwpożarowej, służbach odpowiedzialnych za bezpieczeństwo i porządek publiczny na obszarach kolejowych, służbie zdrowia, a w razie potrzeby także innych właściwych służbach i organach". Tym samym w nowym rozwiązaniu zdefiniowano dużo większą liczbę podmiotów zobowiązanych do zabezpieczenia imprezy, ciągle jednak pozostawała bez odpowiedzi kwestia poruszona w pierwszej części tej publikacji, a mianowicie: kto miałby posiadać główne uprawnienia czy obowiązki dotyczące podjęcia niezwykle trudnego i skomplikowanego procesu koordynacji przedsięwzięć w ramach zapewnienia bezpieczeństwa imprez masowych?

Dotychczasowe doświadczenia nakazują $\mathrm{w}$ odniesieniu do rozwiązań prawnych z 2009 r. podtrzymać wcześniej postawioną tezę o tym, że najodpowiedniejszym organem, który posiadał niezbędne doświadczenie, fachowców, umiejętności w zakresie zarządzania, wiedzę o zagrożeniach była Policja. W żadnej mierze nie należy rozumieć tego postulatu jako możliwości jakiegokolwiek zwolnienia organizatora i innych podmiotów z odpowiedzialności i zakresu koniecznych do spełnienia warunków i wymogów. I choć przypuszczać należy, że tak zwane środowisko policyjne z niechęcią odniosłoby się do tego wniosku, to jednak spokojna analiza tego co miało miejsce wówczas, w ramach przygotowania i organizacji bezpieczeństwa imprez masowych, było właśnie próbą skoordynowania wszystkich przedsięwzięć na rzecz bezpieczeństwa przez Policję. To właśnie Policja miała najwięcej atutów przemawiających za tym, by takiej koordynacji się podjąć, obok wspomnianych już doświadczenia i wykwalifikowanej kadry posiadała też niezbędne zaufanie społeczne gwarantujące aprobatę dla zdecydowanych działań w tym obszarze. A że trudno jej było uciec od tego obowiązku, niech świadczą wypowiedzi polityków, którzy najczęściej w przypadkach niepowodzeń w obrębie zabezpieczenia imprez masowych nakazywali zdwojenie działań i wysiłków właśnie Policji. Znamienna i jednoznaczna była wypowiedź Premiera RP z sierpnia 2013 r.: „Ja będę się pilnował, żeby nie używać słowa »kibic«, gdy mamy do czynienia z bandyta. Sprawdzałem przepisy i za zwykłe uczestnictwo w bójce możliwe jest osadzenie na wiele lat do więzienia - mówił premier, dodając, że policja otrzyma też »jednoznaczne instrukcje co do stosowania przemocy wobec bandytów «. - W Polsce przemoc będą mogli stosować tylko policjanci wobec bandytów" (Premier, 2013). Trudno po tych słowach nie odnieść wrażenia, że ciężar walki 
z bandytyzmem stadionowym pozostaje domeną Policji, tym bardziej że w wielu sytuacjach nie mieliśmy w owym czasie jedynie do czynienia ze zjawiskiem chuligaństwa, ale również z widocznymi przejawami tworzenia się struktur przestępczości zorganizowanej w tym środowisku. Mówił o tym Bartłomiej Sienkiewicz, Minister Spraw Wewnętrznych po spotkaniu w sierpniu 2013 r.: ,[...] mamy do czynienia nie tyle $\mathrm{z}$ fanami piłki nożnej czy środowiskami politycznymi, ale z bandytami”. Przytaczając dane CBŚ z ostatnich dwóch lat, minister powiedział, że w tym okresie zatrzymano 959 stadionowych bandytów, którym postawiono łącznie prawie 1900 zarzutów dotyczących kierowania zorganizowaną grupą przestępczą (11 przypadków) i udziału w niej (192), zabójstwa (14), udziału w bójce (289), rozboju, kradzieży i wymuszenia (217) oraz popełnienia przestępstw narkotykowych (526) (Sienkiewicz, 2013). Nie podlega żadnej dyskusji to, że tam gdzie pojawia się przestępczość zorganizowana, tam nie może zabraknąc Policji. Pytanie jednak, czy idąc tym tokiem myślenia, Policja powinna podjąć się koordynacji szerszego zakresu zadań w trosce o bezpieczeństwo imprez masowych jako całości?

Odpowiedź na to pytanie częściowo przyniosły doświadczenia wynikające z przygotowanie bezpieczeństwa turnieju finałowego EURO 2012. Aby w ogóle organizacja tego przedsięwzięcia była możliwa w krajach partnerskich Polski i Ukrainy, niezbędne były gwarancje rządowe. Jedną z podstawowych gwarancji była ta złożona przez MSWiA. Z punktu widzenia bezpieczeństwa miała ona priorytetowe znaczenie. To MSWiA zobowiązało się do podjęcia wszelkich możliwych środków w celu zagwarantowania bezpieczeństwa ,wszystkich wyznaczonych osób oraz wszystkich pozostałych osób uczestniczących w UEFA EURO 2012, na terenie państwa gospodarza mistrzostw"'. Gwarancje bezpieczeństwa oznaczały wprost bezpośrednie zaangażowanie się resortu spraw wewnętrznych w przygotowanie szerokiego komponentu bezpieczeństwa mistrzostw z koniecznością podjęcia się roli koordynatora tych przedsięwzięć. Jak już podkreślono, jednym z głównych elementów organizacji turnieju finałowego EURO 2012 stało się zapewnienie bezpieczeństwa. Było ono troską wielu podmiotów, przede wszystkim MSWiA, a w jego ramach takich jednostek, jak: Policja, Państwowa Straż Pożarna, Straż Graniczna oraz Biuro Ochrony Rządu. Zarządzeniem nr 9 Ministra Spraw Wewnętrznych i Administracji z 16 stycznia 2008 r. powołano Zespół do spraw koordynacji działań służb podległych MSWiA w związku z organizacją Mistrzostw Europy w Piłce Nożnej EURO 2012. Do głównych zadań Zespołu należało opracowanie koncepcji działań Ministra Spraw Wewnętrznych i Administracji oraz służb podległych w zakresie zapewnienia bezpieczeństwa i porządku publicznego na terytorium Rzeczpospolitej Polskiej. W ujęciu krajowym niezbędne okazało się powołanie struktury koordynującej wszystkie zadania podejmowane w dziedzinie bezpieczeństwa. W maju 2010 r. powstał Komitet do spraw Bezpieczeństwa Mistrzostw Europy w Pitce Nożnej UEFA EURO 2012 ${ }^{6}$. Do jego podstawowych zadań należało wskazywanie obszarów aktywności administracji rządowej w zakresie działań związanych z bezpieczeństwem EURO 2012, ocena stanu realizacji przedsięwzięć zwią-

${ }^{5}$ Gwarancja nr 10 z 23 czerwca 2005 r., podpisana przez Tadeusza Matusiaka - sekretarza stanu w MSWiA. Materiał przekazany przez Biuro Sztabu Komendy Głównej Policji (dalej jako: KGP).

${ }^{6}$ Komitet powstał na podstawie Zarządzenia nr 33 Prezesa Rady Ministrów z 12 maja 2010 r. jako organ pomocniczy Prezesa Rady Ministrów. 
zanych z bezpieczeństwem, prowadzenie polityki informacyjnej (współpraca z mediami), przygotowanie jednolitych opracowań i stanowisk na potrzeby Prezesa Rady Ministrów. Zgodnie z Zarządzeniem Prezesa Rady Ministrów, Komitet monitorował proces przygotowań do EURO 2012 w zakresie bezpieczeństwa, przedstawiając Prezesowi Rady Ministrów w sposób cykliczny informacje na temat postępów. Kluczową rolę w Komitecie odgrywał przewodniczący w osobie Ministra Spraw Wewnętrznych i Administracji (w praktyce był to podsekretarz stanu w MSWiA - Adam Rapacki). Wiceprzewodniczącym Komitetu został Minister Sportu i Turystyki, natomiast członkami przedstawiciele poszczególnych służb, tj. Komendant Główny Policji, Szef Agencji Bezpieczeństwa Wewnętrznego, Komendant Główny PSP, Komendant Główny SG, Dyrektor Rządowego Centrum Bezpieczeństwa, Szef Służby Celnej, Sekretarz Kolegium do spraw Służb Specjalnych, Prokurator Generalny, Szef BOR, Komendant Główny Żandarmerii Wojskowej, wojewodowie (mazowiecki, podkarpacki, dolnośląski, lubelski, pomorski i wielkopolski). Tak przygotowana struktura dawała możliwość realnego wpływu i oceny stopnia bezpieczeństwa w poszczególnych obszarach, w tym pełnego koordynowania przedsięwzięć oraz natychmiastowego, wyprzedzającego reagowania na pojawiające się zagrożenia. Ponadto umożliwiała podejmowanie decyzji dotyczących nie tylko jednego podmiotu, lecz wszystkich uczestników procesu związanego z przyszłym bezpieczeństwem turnieju. To nowoczesne interdyscyplinarne podejście sprzyjało minimalizacji i likwidacji pojawiających się zagrożeń. Słowem, pozwalało na podjęcie natychmiastowych działań adekwatnych do pojawiających się zagrożeń.

Należy wyrazić przekonanie, że takie skoordynowane podejście do bezpieczeństwa, jakie było widoczne w 2012 r., było przejawem najwyższej troski o sprostanie wymogom nowoczesnego zarządzania bezpieczeństwem. Wtedy, z uwagi na szczególnie masowy charakter tej imprezy, mieliśmy do czynienia ze znacznie szerszą koniecznością realizacji wielu przedsięwzięć, które musiały obejmować zakres kompetencyjny wielu podmiotów. Wydaje się jednak, że bezcenne było to, iż zebrano wówczas szereg doświadczeń po stronie każdego z podmiotów, jak i po stronie głównego koordynatora, czyli MSWiA.

Wypadkową tych doświadczeń, jak się wydaje, jest kolejna zmiana (nowelizacja) ustawy o bezpieczeństwie imprez masowych z 2015 r., która wprowadziła między innymi taki zapis:

„Art. 11a.1. Organem pomocniczym wojewody w zakresie zapewnienia wykonywania zadań związanych z bezpieczeństwem imprez masowych jest wojewódzki zespół interdyscyplinarny do spraw bezpieczeństwa imprez masowych, zwany dalej »zespołem«, powoływany przez wojewodę, który określa jego skład, szczegółowy zakres obowiązków oraz tryb działania.

2. Zespołowi przewodniczy wojewoda lub wyznaczony przez niego przedstawiciel.

3. W skład zespołu wchodzą:

1) właściwy miejscowo komendant wojewódzki (Komendant Stołeczny) Policji lub wyznaczony przez niego przedstawiciel;

2) właściwy miejscowo komendant wojewódzki Państwowej Straży Pożarnej lub wyznaczony przez niego przedstawiciel;

3) przedstawiciele innych organów administracji rządowej i samorządowej, których obecność wojewoda uzna za uzasadnioną. 
4. Do udziału w posiedzeniach zespołu wojewoda może zaprosić przedstawicieli związków sportowych, podmiotów prowadzących rozgrywki, organizatorów cyklicznych imprez masowych oraz instytucji i podmiotów, których przedmiot działalności pozostaje w związku z przedmiotem posiedzenia zespołu, których obecność uzna za uzasadnioną lub na ich wniosek" (Ustawa, 2009: art. 11a).

W dalszej części tego nowego rozwiązania prawnego czytamy, że ideą nadrzędną powołania omawianego zespołu była przewidywana pomoc, jaką może on udzielić podmiotom zajmującym się przygotowaniem bezpieczeństwa imprez w danym województwie. Pomoc ta w szczególności miałaby polegać na: analizie zagrożeń, wymianie informacji czy popieraniu inicjatyw zmierzających do poprawy stanu bezpieczeństwa organizowanych imprez masowych. Rozwiązanie to przypomina nieco (w skali mikro) kształt komitetu, który odpowiadał za przygotowanie zabezpieczenia finałowego turnieju EURO 2012. Szkoda jednak, że nie wskazano tego interdyscyplinarnego podmiotu jako koordynatora przedsięwzięć podejmowanych na rzecz bezpieczeństwa imprez masowych.

Jest to też w pewnym sensie wyraz filozofii podejścia do zagadnień bezpieczeństwa, z jaką mieliśmy do czynienia w 2012 r., jednak brakuje przysłowiowej kropki nad „i”. $\mathrm{W}$ przypadku tamtego turnieju finałowego wyeksponowano przewodnią rolę Ministra Spraw Wewnętrznych i Administracji. W omawianym, nowym rozwiązaniu prawnym wskazuje się na ważną rolę wojewody, który powołuje organ pomocniczy, jakim jest zespół interdyscyplinarny do spraw bezpieczeństwa imprez masowych. Można sobie wyobrazić, iż w przypadku meczów piłkarskich o szczególnym zagrożeniu na terenie województwa czy imprezy masowej o charakterze międzywojewódzkim w prace zespołu zaangażuje się wiele podmiotów, a nawet osobiście wojewoda. Jednak brak jasnego wskazania, iż jest to lub ma być organ koordynujący działania, może w konsekwencji prowadzić jedynie do oceny pracy poszczególnych ogniw, co będzie tylko wycinkiem działań rozumianych jako skoordynowane podejście do zagadnień bezpieczeństwa. Pozostaje jeszcze jedna kwestia - jest nią troska o jakość pracy i niezbędną wiedzę ,przedstawiciela wojewody", który będzie mógł kierować takim ogniwem. Zdaniem autora niniejszej publikacji, element ten jest bardzo ważny, jeśli nie decydujący o tym, jaki kształt przybiorą spotkania zespołu. Nie jest więc obojętne to, kim będzie ów przedstawiciel. Jednym z rozwiązań zmierzających do poszukiwania najlepszych z możliwych kandydatów jest możliwość prześledzenia systemu dowodzenia EURO 2012 i wykorzystania tych ludzi, którzy pełnili w tym systemie różnorakie funkcje dowódczo-koordynacyjne i to zarówno po stronie rozlicznych służb, jak i tzw. czynnika cywilnego (miejskiego). Ta rada dotyczy jednak wąskiego zakresu obszaru kraju, głównie miast gospodarzy turnieju EURO 2012. Nie ulega jednak wątpliwości, iż największe doświadczenie, od momentu wejścia w życie pierwszego rozwiązania ustawowego dotyczącego bezpieczeństwa imprez masowych w 1997 r. do współczesnych rozwiązań, mają obecni i byli funkcjonariusze Policji. To właśnie w gronie byłych funkcjonariuszy Policji można znaleźć doskonałych fachowców, Naczelników Wydziałów Komend Wojewódzkich, zastępców, a nawet komendantów wojewódzkich Policji, którzy doskonale mogą realizować zadania przedstawiciela wojewody, o którym mówi nowe rozwiązanie prawne z końca 2015 r. Obok wiedzy, często posiadają oni również niezbędny autorytet wśród podmiotów, które będzie angażował do współpracy zespół interdyscyplinarny wojewody. 
To nowe rozwiązanie ustawowe, choć niezwykle ważne, nie zapewni automatycznie poprawy poziomu bezpieczeństwa w szeroko rozumianym zakresie imprez masowych. Potrzeba dobrej woli i zrozumienia wagi problematyki przez wszystkie podmioty zespołu wojewody, ale również konsekwencji w działaniach polityków. W nieco innym wymiarze zwracają na to uwagę autorzy Białej Księgi Bezpieczeństwa Narodowego RP: „Najważniejszym i warunkującym wszelkie inne działania jest uzyskanie zgodności (konsensusu) wszystkich sił politycznych co do politycznej woli priorytetowego traktowania spraw bezpieczeństwa narodowego w polityce państwa" (Biała Księga, 2013: 156). Tak jak w przypadku bezpieczeństwa narodowego, tak i w odniesieniu do bezpieczeństwa imprez masowych konieczne jest wykazywanie dobrej woli politycznej na przestrzeni wielu lat, by zapewnić stabilność i wizję walki ze zjawiskiem chuligaństwa stadionowego. Policja i wiele innych organów zajmujących się tym zagadnieniem musi mieć pewność, że podejmując ten trud dzisiaj, gwarantuje sobie aprobatę i wsparcie polityczne w tym obszarze bez względu na kolejne zmiany polityczne w kraju. Inaczej walka z bandytyzmem związanym z imprezami masowymi będzie miała jedynie incydentalny charakter, a wszelkie dobre rozwiązania będą „odgrzewane" na nowo co kilka lat.

Podsumowując, na przestrzeni 20 lat od momentu uchwalenia pierwszej ustawy mającej za zadanie uporządkowanie zakresu działań i odpowiedzialności w obszarze zabezpieczania imprez masowych mamy dziś dobre rozwiązania prawne, które być może będą podlegały kolejnym niezbędnym ewolucjom. Jak się wydaje mamy wreszcie wskazanego (choć szkoda, że nie wprost) lidera tego obszaru, który może podjąć się skoordynowania wszelkich przedsięwzięć. Wartość koordynacji została udowodniona w trakcie przygotowań i realizacji zadań związanych z EURO 2012. Dzięki skupieniu wielu podmiotów odpowiedzialnych za bezpieczeństwo w jednym obszarze, koordynowanym w fazie przygotowań przez Komitet do spraw Bezpieczeństwa EURO 2012, a później przez Krajowy Sztab Operacyjny z główną rolą MSWiA, można było przeprowadzić bezpieczne mistrzostwa na terenie Polski. I choć sceptycy powiedzą, że i tak doszło do naruszeń prawa i zbiorowego zakłócenia bezpieczeństwa i porządku publicznego w związku z meczem pomiędzy Polską a Rosją, to jednak zdawać sobie trzeba sprawę z tego, że całkowite wyeliminowanie takich zdarzeń nie jest możliwe. Dzięki zaś precyzyjnemu procesowi koordynacji można się do nich zdecydowanie lepiej przygotować i skuteczniej przeciwstawiać. Czas już, by takie działanie stało się na zawsze kanonem przygotowań imprez masowych, zwłaszcza sportowych, w tym oczywiście meczów piłki nożnej. Choć trzeba przewidywać i to, że w przypadku konsekwentnej i skutecznej walki z bandytyzmem i przestępczością okołostadionową związaną z rozgrywkami piłkarskimi zagrożenie to może się przenieść i na inne dyscypliny. Taki pogląd przedstawia Wiesław Pływaczewski przewidując, że bardziej skuteczne działania policji oraz innych służb odpowiedzialnych za bezpieczeństwo meczów piłkarskich zmuszą niektóre frakcje bojówek kibicowskich do wyboru mniej ryzykownych dyscyplin, takich jak koszykówka, siatkówka itp. (Pływaczewski, 2010: 30). W dużej mierze zależeć to będzie od skuteczności podjętych działań, jeżeli takimi się one okażą. Trzeba też już dziś przemyśleć kompleks działań zapobiegawczych w stosunku do dyscyplin, które również w warunkach polskich gromadzą na trybunach duże rzesze kibiców. Dzisiaj wydaje się to mało prawdopodobne, jednak nie niemożliwe. 
Bezpieczeństwo publiczne zawsze będzie domeną Policji. Społeczeństwo ma pełne prawo oczekiwać skutecznych rezultatów w walce z przestępczością i bandytyzmem na stadionach. Te działania będą jednak o tyle bardziej skuteczne, o ile więcej, ważnych z punktu widzenia bezpieczeństwa, podmiotów zaangażuje się w realizację tych przedsięwzięć. Pamiętać wszakże należy o jednym, suma części tak długo nie stanowi całości, dopóki nie zostanie zespolona w jeden organizm. Takiej misji powinny się podjąć zespoły interdyscyplinarne do spraw bezpieczeństwa imprez masowych.

\section{BIBLIOGRAFIA}

Biała Księga Bezpieczeństwa Narodowego Rzeczypospolitej Polskiej (2013), Biuro Bezpieczeństwa Narodowego, Warszawa.

Dudała J. (2004), Fani - chuligani - rzecz o polskich kibolach, Warszawa.

Dyduch L. (2010), Możliwości zapobiegania przestępstwom wobec policjantów zabezpieczajacych imprezy masowe, w: Przestępczość stadionowa, etiologia, fenomenologia, przeciwdziałanie zjawisku, (red.) W. Pływaczewski, J. Kudrelek, Szczytno.

Ekstraklasa. Zadyma na stadionie (2010), http://wiadomosci.gazeta.pl/wiadomosci/1,114873,85962 97,Ekstraklasa_Zadyma_na_stadionie_Obiekt_Lecha_kompletnie.html (2.10.2017).

Gozdór G. (2008), Bezpieczeństwo imprez masowych. Komentarz, wyd. C.H. Beck, Warszawa.

Gozdór G. (2012), Prywatyzacja bezpieczeństwa. Rola i miejsce prywatnego sektora ochrony w systemie bezpieczeństwa i porzqdku publicznego, Lublin.

Karolczak-Biernacka B. (2001), Agresywny sport w agresywnym świecie, ,Sport Wyczynowy”, nr 7-8.

Kołek K., Mikołajczyk P. (2010), Etiologia przestępczości stadionowej i chuligaństwa futbolowego oraz analiza wybranych koncepcji ich zwalczania, w: Przestępczość stadionowa, etiologia, fenomenologia, przeciwdziałanie zjawisku, (red.) W. Pływaczewski, J. Kudrelek, Szczytno.

Kotowski W., Kurzępa B. (2010), Bezpieczeństwo imprez masowych. Komentarz do ustawy o bezpieczeństwie imprez masowych, wyd. Difin, Warszawa.

Krawczuk A. (1992), Poczet cesarzy bizantyjskich, Warszawa.

Pływaczewski W. (2010), Zorganizowane formy przestęstwa na tle zjawiska tzw. przestęczości stadionowej, w: Przestępczość stadionowa, etiologia, fenomenologia, przeciwdziałanie zjawi$s k u$, (red.) W. Pływaczewski, J. Kudrelek, Szczytno.

Premier Tusk: Z bandytami trzeba walczyć skutecznie, niekiedy brutalnie (2013), http://wyborcza. pl/1,76842,14466442,Premier_Tusk_Z_bandytami_trzeba_walczyc_skutecznie_html (14.02.2017).

Sienkiewicz: monopol na przemoc ma państwo, nie bandyci (2013), http://wiadomosci.onet.pl/kraj/ bijatyki-z-udzialem-pseudokibicow-zdecydowana-reakcja-ministra/k6lmv (14.02.2017).

Tyburska A. (2001), Zapewnienie bezpieczeństwa imprez masowych w kontekście Mistrzostw Europy w Piłce Nożnej Euro 2012, w: Przestępczość stadionowa, etiologia, fenomenologia, przeciwdziałanie zjawisku, (red.) W. Pływaczewski, J. Kudrelek, Szczytno.

Ustawa z 20 marca 2009 r. o bezpieczeństwie imprez masowych (2009), Dz. U. 2009, Nr 62, poz. 504.

Ustawa z 20 marca 2009 r. o bezpieczeństwie imprez masowych (2015), Dz. U. 2015, poz. 2139.

Ustawa z 22 sierpnia 1997 r. o bezpieczeństwie imprez masowych (1997), Dz. U. 1997, Nr 106, poz. 680.

Ustawa z 6 kwietnia 1990 r. o Policji (1990), Dz. U. 1990, Nr 30, poz. 179. 


\title{
STRESZCZENIE
}

W niniejszej publikacji przedstawiono znaczenie działań związanych z koordynacją przedsięwzięć zmierzających do prawidłowego przygotowania i kierowania bezpieczeństwem imprez masowych. Ustawodawstwo polskie obejmujące ten zakres tematyczny zagadnień, wskazywało już od 1997 r. proces koordynacji jako ważny element budowy bezpieczeństwa imprez masowych, który właściwego znaczenia nabrał dopiero przed turniejem finałowym Euro 2012. Nadal jednak, w obowiązujących regulacjach prawnych, nie wskazano koordynatora tego procesu, tym samym również jego obowiązków. Autor publikacji stara się zwrócić uwagę na konieczność rozwiązania tego problemu w przyszłych regulacjach prawnych.

Słowa kluczowe: bezpieczeństwo, policja, imprezy masowe, zagrożenia

\section{MASS EVENTS SECURITY COORDINATION IN POLISH LAW AND PRACTICE}

\begin{abstract}
This publication presents the importance of the coordination of initiatives aimed to correct preparation and safety management events. Polish legislation covering the thematic range of issues, indicated since 1997 the coordination process, as an important element of the construction of the security of mass events, which took the proper meaning just before the final tournament Euro 2012. Still, in the current regulations, coordinator of this process is not indicated, neither his duties. Author of the paper tries to draw attention to the need to solve this problem in future regulations.
\end{abstract}

Keywords: security, police, mass events, threats 
